\title{
Phaeochromocytoma presenting as an acute abdomen: report of two cases
}

\author{
DAVID J JONES, PATRICIA DURNING
}

Phaeochromocytomas are catecholamine secreting tumours, usually arising in the adrenal medulla. The most common clinical manifestation is hypertension, although many symptoms and signs have been described.' Presentation as an acute abdominal emergency is rare. We describe two such cases, which presented within three weeks of each other to a district general hospital.

\section{Case 1}

A 55 year old man presented having suddenly developed severe, constant left sided abdominal pain and vomiting three hours earlier. He appeared profoundly shocked, with a sinus tachycardia of 160 beats/min and a blood pressure of $160 / 110 \mathrm{~mm} \mathrm{Hg}$. There was a large, tender, ballotable left sided abdominal mass.

Results of investigations were: haemoglobin concentration $145 \mathrm{~g} / \mathrm{l}$, white cell count $25 \cdot 3 \times 10^{9} / 1$, serum amylase activity $4310 \mathrm{IU} / 1$, and glucose concentration $9.9 \mathrm{mmol} / 1(178 \mathrm{mg} / 100 \mathrm{ml})$. Urgent ultrasound scan showed a large retroperitoneal mass with solid and cystic areas. The spleen and lef kidney could not be distinguished. Intravenous urography showed a normal but laterally displaced left kidney and renal tract.

He continued to appear profoundly shocked, and we proceeded to laparotomy, suspecting massive intra-abdominal haemorrhage. In the operating room he developed severe pulmonary oedema soon after induction of anaesthesia. Laparotomy disclosed a huge left sided retroperitoneal mass containing a haematoma. The pancreas was entirely normal. Further surgery was abandoned owing to the patient's poor condition.

Intermittent positive pressure ventilation was continued postoperatively. His tachycardia had persisted at $160 / \mathrm{min}$ and blood pressure was stable at $160 / 90 \mathrm{~mm} \mathrm{Hg}$. There was profound peripheral vasoconstriction, which was not relieved by an infusion of sodium nitroprusside. A phaeochromocytoma was suspected and blood samples taken for estimation of catecholamine values. The patient died before the response to $\alpha$ and $\beta$ blockers could be tested.

At necropsy a $22 \mathrm{~cm}$ diameter haemorrhagic phaeochromocytoma of the left adrenal was found, weighing $2180 \mathrm{~g}$. Death was due to acute left ventricular failure. The plasma noradrenaline concentration immediately before death was $1150 \mathrm{nmol} / 1(195.0 \mathrm{ng} / \mathrm{ml})$ (normal $1-6 \mathrm{nmol} / \mathrm{l} ; 0 \cdot 17$. $1.02 \mathrm{ng} / \mathrm{ml}$ ).

\section{Case 2}

A 77 year old woman presented with an eight hour history of severe constant pain in the right hypochondrium, vomiting, and rigors. She also complained of attacks of palpitations for two years. On examination she was obviously in pain; she was sweating but had no fever, pulse was $110 / \mathrm{min}$ and irregular with multiple extrasystoles, and blood pressure was $150 / 90 \mathrm{~mm} \mathrm{Hg}$. There was guarding and tenderness with rebound in the right hypochondrium

Results of investigations were in keeping with a diagnosis of acute

Stepping Hill Hospital, Stockport SK2 7JE

DAVID J JONES, MB, FRCS, registrar in surgery

PATRICIA DURNING, MB, FRCS, registrar in surgery

Correspondence to: $\mathrm{Mr}$ Jones.
Phaeochromocytoma may rarely present as an acute abdominal emergency; without prompt, appropriate treatment and removal of the tumour death is likely

cholecystitis (haemoglobin concentration $151 \mathrm{~g} / \mathrm{l}$, white cell count $18.9 \times 10^{9} / 1$, radiological evidence of gall stones), and she was treated conservatively with intravenous fluids and antibiotics. Twelve hours after admission she became shocked (pulse 130/min; systolic blood pressure $80 \mathrm{~mm} \mathrm{Hg}$ ); her abdominal signs remained unchanged.

We proceeded to laparotomy, suspecting a perforated gall bladder. At operation there was a small quantity of blood in the peritoneal cavity and a large haematoma affecting the right kidney and adrenal. There were multiple stones in her gall bladder. A large haemorrhagic tumour of the right adrenal was removed with minimal blood loss. Postoperatively we were unable to improve her cardiac output. She had a persistent tachycardia of $180 /$ min and no recordable blood pressure, despite blood transfusion and dopamine infusion.

She died four hours postoperatively. Histological examination confirmed an adrenal phaeochromocytoma $3 \mathrm{~cm}$ in diameter.

\section{Discussion}

Small areas of haemorrhage are commonly found in phaeochromocytomas. It is unusual to find haemorrhagic necrosis severe enough to manifest as an acute abdominal emergency. ${ }^{2-6}$ The most common clinical feature is severe, constant abdominal or loin pain and tenderness, often with vomiting. Occasionally a mass may be palpable. Disruption of the phaeochromocytoma may result in massive release of catecholamine and features of intense sympathetic stimulation-sweating, tachycardia, hypertension, and peripheral vasoconstriction. Progressive or total destruction of the tumour may lead to a pronounced reduction in catecholamine secretion and hypotension, analogous to that observed after surgical removal of a phaeochromocytoma. These events are easily interpreted if a phaeochromocytoma has already been diagnosed. If, however, haemorrhagic necrosis is the mode of presentation confident exclusion of other abdominal emergencies is difficult-for example, ruptured aortic aneurysm, mesenteric infarction, acute pancreatitis, cholecystitis. The incidence of cholelithiasis is greatly increased in patients with phaeochromocytoma. ${ }^{1}$ Haemorrhagic necrosis may be precipitated by phenothiazines' and has been observed in patients receiving anticoagulants. ${ }^{\text {is }}$

Emergency laboratory investigation may yield non-specific abnormalities such as leucocytosis and mild hyperglycaemia. Plain abdominal radiography, intravenous urography, and ultrasound examination are practicable and may be helpful. Results of urine and plasma catecholamine analysis are unlikely to be obtained in time to be of help. Correct diagnosis therefore depends on recognising the clinical picture of haemorrhagic necrosis.

Elective resection of phaeochromocytomas with pharmacological control has a low mortality, but surgery in undiagnosed patients is associated with a high mortality. Successful removal of phaeochromocytomas presenting with haemorrhagic necrosis has been 
described. ${ }^{46}$ The emergency condition should be controlled pharmacologically before surgical removal of the tumour. In case 1 there was a massive release of noradrenaline, and adrenergic blockade may have restored homoeostasis. In case 2 destruction of the tumour resulted in a need for catecholamine administration.

A high index of suspicion is necessary to diagnose this unusual cause of an acute abdomen. Without prompt and appropriate treatment death is likely.

We thank Mr M Davies, Mr PC England, and Mr J Hewet for allowing us to report these cases.

\section{References}

1 Manger WH, Gifford RW Jr. Pheochromocytoma. Berlin: Springer-Verlag, 1977.

2 Gilliland IC, Daniel O. Phaeochromocytoma presenting as an abdominal emergency. Br Med $\mathcal{J}$ 1952; $;$ ii: $275-7$

3 Jellife RS. Phaeochromocytoma presenting as a cardiac and abdominal catastrophe. $\mathrm{Br}$ Med $\mathrm{J}$ 1952;ii:76-7.

4 Huston JR, Steward WRC. Hemorrhagic pheochromocytoma with shock and abdominal pain. Am J Med 1965;39:502-4.

5 Ejerblad S, Hemmingsson A. Haemorrhage into a phaeochromocytoma in an anti-coagulanttreated patient. Acta Chir Scand 1981;147:497-500.

6 Nicholls K. Massive adrenal haemorrhage complicating adrenal neoplasm. Med 7 Aust 1979;ii:560-2.

(Accepted 16 May 1985)

\section{MATERIA NON MEDICA}

\section{Sky fishing}

Our current obsessions are kites and Crete. This spring they were brought together. I bought a "high tech" kite from Greens of Burnley and a holiday from Thomsons. Crete is very windy and windmills of all shapes and sizes stand out from the fields, vineyards, and olive groves. It seems that every level stretch of land is under cultivation or covered with impenetrable gorse - the death of kites.

The problem of location was not solved until our second week. Gournia is a Minoan town whose last occupants died, probably violently in a tidal wave, 3400 years ago when Santorini, 80 kilometres to the north, exploded. It is the most complete town of that era to be excavated and, after Lato, is the most imagination stirring place that I know. Between Gournia and the sea is the Heraklion-Sitia road and a plain of scrub and scented herbs. We found a rocky ravine, one kilometre long and about 100 metres wide at the seaward end; an on shore breeze completed the equation and we unpacked the kite.

It was a sparless kite about the size of a cot mattress; once out of its pocket sized bag it took on a life of its own, entangling my wife in its rigging and attempting lift off while she struggled to disengage herself. When they parted company the kite soared away strongly. At the full length of the line it was nearly vertically above me and the tension in the line allowed the singing of the wind in the rigging to be heard from the wooden frame in my hand. Kite flying has the same sort of appeal as fishing. Aerial fishing-for clouds perhaps.

Later that day we flew a small stunter kite on a beach a few kilometres east of Ierapetra on the Libyan Sea, and a small audience of Greeks "bravoed" every gyration. I had never seen a kite in Crete before-and I did not think they had either, but I was wrong.-MICHAEL CONWAY, Manchester.

\section{Torpor melitensis}

Not having been to Malta before we had made plans to explore the island, follow its extraordinary history in its monuments, walk, sketch, rush hither and thither, and fill the gaps in our programme with swimming and eating. Now, after a two week holiday, I have to confess that almost none of this has been achieved and we have spent the time sunk into an indolent and unexpected torpor. This has not been the wilful stupor of the sunseekers, oiled and supine by the pool, EEGs flat, unrousable except when reanointing nipples and noses and rotating with the sun. Our torpor is, by contrast, unplanned and largely unwelcome and I suspect endemic among North Europeans transiently in and around the Mediterranean. Nevertheless, clinical curiosity demands some reasons for it. Temperatures in the $90 \mathrm{~s}$ and a high humidity perhaps? Hardly, and if so, by what mechanism? The Knights of St John in full armour battled with the invading Turks throughout the summer of 1565 presumably without too much torpor for they won against all the odds, though di Correggio does admit that on one day at least an equal number died of the heat as died in battle. Alcohol perhaps-unaccustomed wines at unusual times of day, maybe rendered stronger by subclinical dehydration. Maybe it's the food. Grilled swordfish and lampuki pie are unusual fare but nothing strange is added. Perhaps the unaccustomed exercise of regular swimming leaves one just plain tired. I think not. The Mediterranean is buoyant, blue, warm, and relaxing and certainly doesn't call up the vigorous efforts needed to keep at bay the chill of the English Channel. Could it just be a slackening of taut nerves brought on by escape from the telephone, outpatients, and an in tray full of brown envelopes? Is it, as they say in MCQs, "all of these, some of these, or none of these?"

It cannot, by the way, be Malta fever, alias brucellosis, because the milk comes pasteurised from cows, chink chink in bottles every morning just as it does at home.

I expect the symptoms will remit when we get home but the problem might justify some proper research-if anyone can summon up the energy to do it.-A E YOUNG, consultant surgeon, London.

\section{Whistle while you talk}

Whistling is a pleasant way of whiling away the time and, like listening to a brass band, it uplifts the spirits. Oddly, it is produced only by humans; bird calls are produced in a different way and are not true whistles. Whistling may be used to attract attention over longish distances or to give coded information, as in controlling sheepdogs. It is also frequently employed to express amazement or derision or merriment. However, in each case the information conveyed is strictly limited.

In certain parts of the world whistling is used as a language form. These areas are usually mountainous, where the transmission of information over even short distances by spoken language would be difficult because of the terrain. The whistle languages are not methods of coded information transmission, but are normal languages spoken through a whistle. For this to be accomplished the whistle languages are basically polysyllabic. As there is a distortion of speech production when also producing a whistle, the use of polysyllabic words overcomes the possible misunderstanding of the distorted speech. Examples of this type of speech occur in the island of Gomera in the Canary Islands off the west coast of Africa (La Gomeran) and in the speech of the Mazateco Indians of Oaxaca in Mexico. Other examples have been reported in Nepal and New Guinea. La Gomeran is a whistled form of Spanish. It is estimated that in the Spanish language $80 \%$ of the words are of three or more syllables, while in both French and English only $20 \%$ of the vocabulary consists of words of three or more syllables. Gross inaccuracies of comprehension would result from whistled French or English. Chinese, although a tonal language, is monosyllabic and would be completely unsuitable as a whistle language.

In both Mazateco and La Gomeran convention limits the use of the whistled language to males, although females understand it. Cowan writes: "One day Chumi was standing idly in the doorway of our hut. Irene Flores was working around the hut. No one it seems was paying any attention to the quiet, random whistlings of a boy so nonchalantly leaning against the doorpost. All of a sudden, however, Irene whirled and launched out in a terrific scolding in spoken Mazateco. The whistling had not been so innocuous as it appeared. The mischievous boy had actually been whistling some very meaningful things to the girl....",

The great advantage of such a language method is its range. Distances of six miles between the conversants have frequently been recorded, although this is somewhat unusual. More normal conversations are across valleys or along hillsides or even a few yards in a crowd. The whistled language is culturally accepted as a natural and integral part of conversation, is used frequently, and may be heard at most times of the day in both Gomera and Oaxaca.

An amusing story is told of one research linguist who was walking down through the woods in the island of Gomera when he heard the words "Santa Maria de los Angeles" being clearly whistled nearby. As he thought there was no one near he was surprised; and more surprised when he discovered the "speaker" was a bird imitating the whistled language.-P R GEISSLER, Edinburgh.

1 Cowan GM. Mazateco whistle speech. Language 1948;24:280-6. . 